\title{
タブレット端末を利用した配筋検査支援システム
}

\author{
金子 智 弥*
}

1.はじめに

鉄筋工事の良否は，鉄筋コンクリート（以下， RC) 構造物の耐力と耐久性を左右する。また，コンクリート 打設後では鉄筋の施工状況の確認は困難であり, 万一不 具合が生じた場合には補修・補強が難しい場合が多い。 したがって墨出しからコンクリート打設までの各工程 で，検査を確実に行うことが重要である。本稿では，鉄 筋が設計図通りに施工されていることを，専門工事会 社・工事管理者・設計監理者が確認する業務を配筋検査 と呼ぶ。

建築工事に打ける配筋検査の実施記録は，従来，検査 によって不具合を指摘された箇所とその是正結果の記録 が中心であった。近年，トレーサビリティーの重要性の 高まりから，検査で適正だった箇所も含め，全箇所の検 查記録が求められている。全箇所の検査記録は, 適正な 工事と検査実施の証明となる一方で，記録業務の工数を 増加させる。

そこで筆者らは，集合住宅の内装工事の検査等を中心 に当社で広く利用している携带端末 ${ }^{1)}$ (Personal Digital Assistant：以下, PDA）を利用して, 全箇所検查記録 を支援する「配筋検査支援システム」を開発し 2009 年 に実用化した2)。また2011年からはPDA よりも操作性 の高いタブレット端末を利用し, 写真管理等の機能強化 を行った。

本稿では, システム開発の目的, PDAを利用したシ ステムの機能と適用効果, そしてタブレット端末導入に 際して行った機能追加について報告する。

\section{2. システム開発の目的}

\section{1 配筋検查業務の調査}

システム開発の必要性を検討するために, 配筋検査業 務の現状調查を行った。

図-1は，5 現場に扮ける躯体工事期間中の管理業務の 比率を工種別に示したグラフである。派遣社員や外注作 業員を含む建築係りの人員配置を元に，ヒアリング調査 によって作成した。その結果，鉄筋工事に関する業務が 1/4を占めていることが分かった。また，その内訳の半 分以上が品質管理業務であった。

* かねこ・ともや/侏大林組 技術研究所 主任研究員
図-2 は，鉄筋工事の品質管理業務の内訳を示してい る。このうち, 全箇所の検査記録を残す場合に工数の増 加が予想される業務は, 検査計測・検査書類作成・工事 写真撮影・工事写真整理であり，全体の $65 \%$ を占める。 全箇所・全数検查記録を実施するためには，情報技術に よるこれらの業務の支援が必要なことが分かった。

このほか, ヒアリング調查から次のような課題が明ら かになった。

1）検查に必要な情報が構造図・施工要領書に散在し ており，検查場所に多くの図面を所持しなければな らない。

2）検査内容が分かる写真を大量に撮影する。写真に は検查筒所の配筋図を書いた黒板を写し込むことが 求められる。

3）大量の検査結果と工事写真を整理し, 検査報告書 を作成する必要がある。

\section{2 システム開発のねらい}

全箇所検査記録の業務負荷を軽隇するため, 以下のね らいでシステムを開発した。

1）検查箇所・写真撮影箇所をあらかじめ明示し, 検

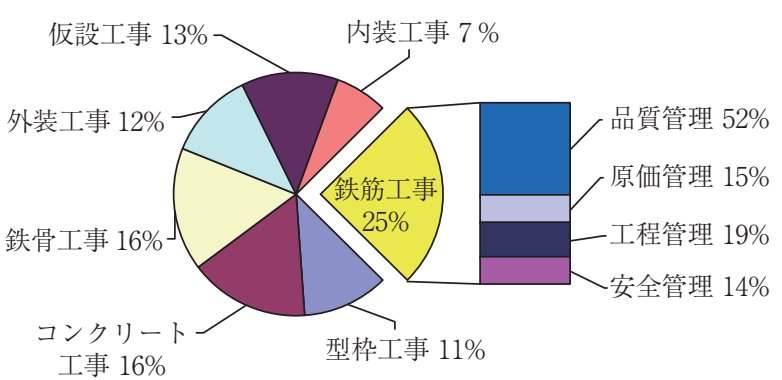

図-1＼cjkstart鉄筋工事の工事管理業務比率

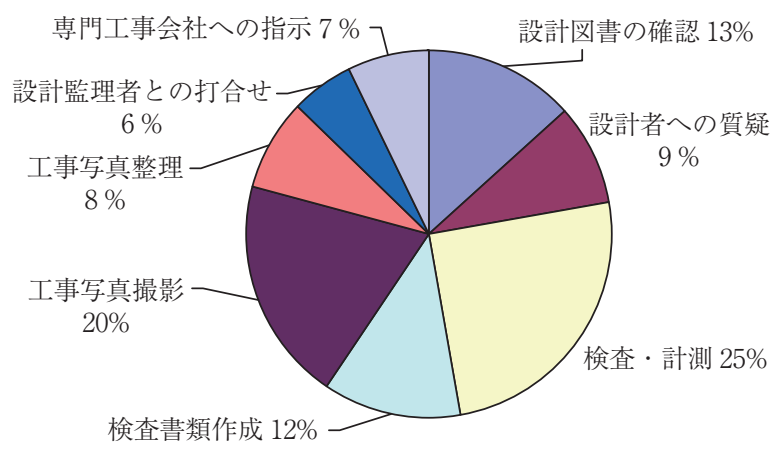

図-2 鉄筋工事の品質管理業務の内訳 
査業務の進渉把握を容易にする。併せて検査漏れも 防ぐ。

2）施工現場では携帯端末を利用し，必要な図面を参 照し，検査結果を記録する。

3）カメラメモ機能付きデジタルカメラを利用し, 工 事写真を自動的に仕分ける。

4）検査票 ·写真帳・是正記録などの帳票作成を迅速 化する。

5）施工現場の検査体制に応じて確認項目を柔軟に設 定できる。

3. PDAを利用したシステムの概要

\section{1 システムの機能}

システムの機能構成を表-1に示す。本システムは, 複数台のパソコン・PDA・デジタルカメラを連携した システムである。パソコンは, 検査結果および工事写真 の管理，検査業務の進渉管理，帳票の作成等の主要な機 能のほか, PDA やデジタルカメラとの連携機能を持つ。 図-3 はパソコンのメイン画面である。PDA にはパソコ ンの機能のうち, 施工現場で検査に必要な機能のみを備 えている。デジタルカメラは，あらかじめパソコンで設 定したキーワードを撮影時に選択して，写真データの EXIF 情報に書込む機能を持っている。

\section{2 システムを利用した業務の流れ}

システムを利用した配筋検査の流れを図-4に示す。 図中に示す「(1) 導入前準備」は施工現場での利用に先 立って行い,「(6) 変更への対応」は随時行う。したがっ て，実際の検査はコンクリート打設工区ごとに「(2) 検 査の準備」から「(5) 検査のまとめ」を繰返して進める。

(1) 導入前準備

施工現場における利用に先立って，配筋検査に必要な 構造図を登録する。図面は CAD データをイメージデー 夕に変換する，または紙図面をスキャナーなどで取り込 む。柱や梁等の断面リストは，符号と階で所定の図面を 呼び出せるように，表形式を指定して取り込む。次に， 検査対象とする部位と部位ごとの確認項目を設定する。 個々の確認項目については，“検査箇所ごとに写真を撮 影する”, “現場で計測した数值を記録する”, などの詳細 を設定する。最後に伏図等の平面図の表示画面上に，検 査箇所を設定する。

（2）検査の準備

施工現場で検査を行う前に, PDAにデータを送信す る。また，デジタルカメラに検査箇所を示すキーワード を転送する。

（3）施工現場での検査

写真-1 はPDA を利用した検査の状況である。PDA の検査内容確認画面を図-5に示す。PDA もパソコンと 同様に，検査箇所が平面図上のアイコンとして表示され る。アイコンを選択すると, 当該箇所の検査箇所の構造
図が表示される。柱や大梁では平面図上の位置が同じで も階によって鉄筋の径・本数・間隔などが異なる場合が ある。このような部位の検査では, 上・下階の構造図も 参照する必要がある。そこで本システムでは常に上・下

表-1 PDA を利用したシステムの機能構成

\begin{tabular}{|c|c|c|}
\hline 機器 & 機能分類 & 機能内容 \\
\hline \multirow{10}{*}{ パソコン } & \multirow{3}{*}{ 配筋検査管理 } & ·検査箇所の設定·変更 \\
\hline & & ·検査進渉状況の確認 \\
\hline & & · 検査結果の帳票作成 \\
\hline & \multirow{2}{*}{ 施工現場個別設定 } & ·確認項目の設定 \\
\hline & & ·帳票書式の設定 \\
\hline & \multirow{3}{*}{ 工事写真管理 } & ·撮影箇所情報の書出し \\
\hline & & ·写真の一括自動仕分け \\
\hline & & ·写真帳の作成 \\
\hline & \multirow{2}{*}{ PDA との同期 } & ·PDA へのデータ書出し \\
\hline & & •PDA からのデー夕取込み \\
\hline \multirow{3}{*}{ PDA } & \multirow{3}{*}{ 配筋確認記録 } & ·検査箇所と検査状況の表示 \\
\hline & & ·構造図・配筋図の表示 \\
\hline & & ·配筋確認結果の記録 \\
\hline \multirow{2}{*}{$\begin{array}{l}\text { デジタル } \\
\text { カメラ }\end{array}$} & \multirow{2}{*}{$\begin{array}{l}\text { 検査箇所情報付き } \\
\text { 真の撮影 }\end{array}$} & ·撮影箇所情報の選択 \\
\hline & & • 撮影箇所情報付き写真の撮影 \\
\hline
\end{tabular}

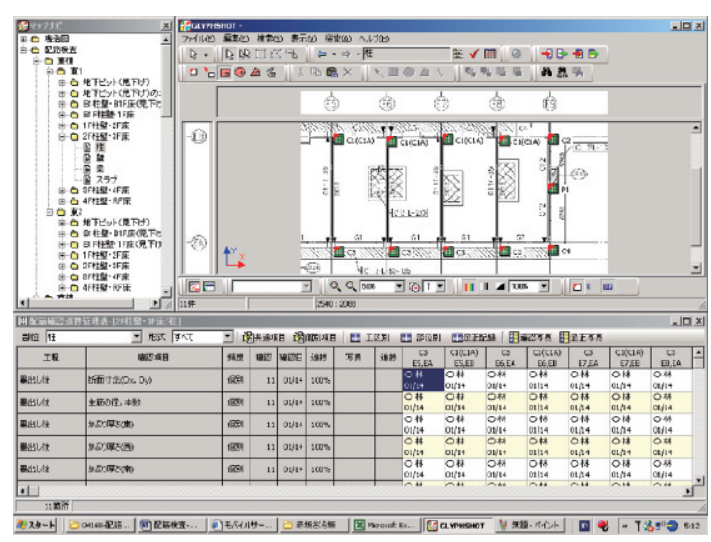

図-3パソコンの配筋検査進渉管理画面

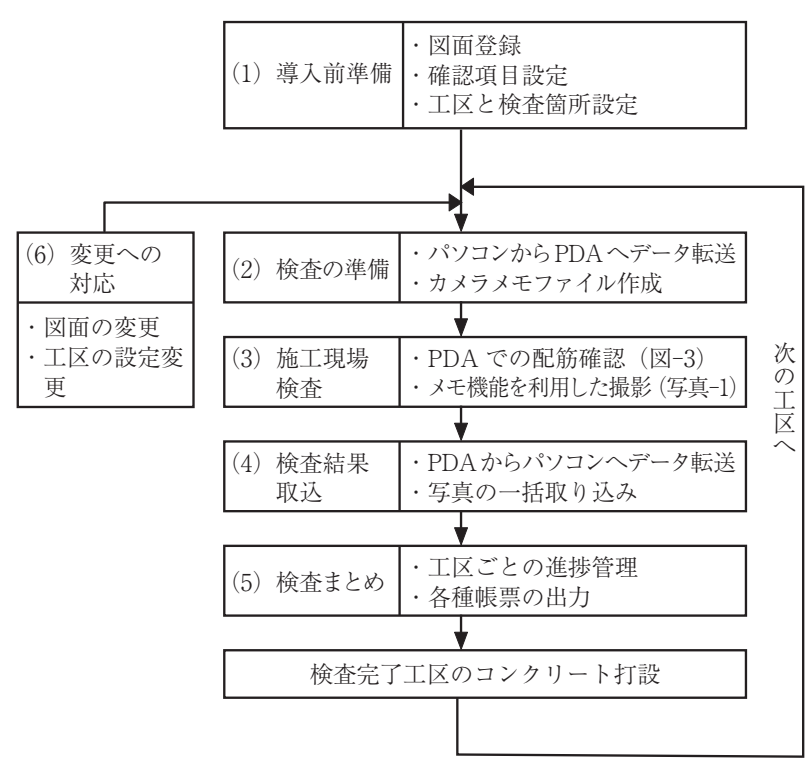

図-4システムを利用した配筋検査 


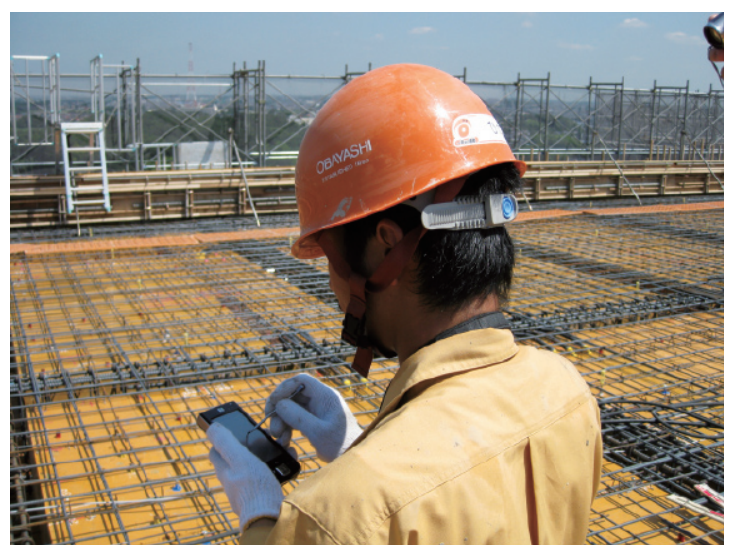

写真-1 PDA による検査の状況

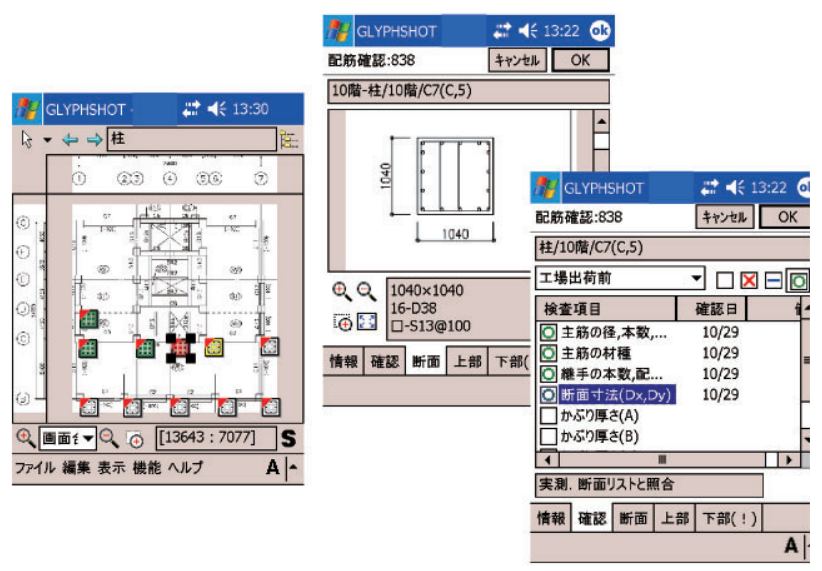

（a）平面図表示画面
表-2 システム適用の概要

\begin{tabular}{c|c}
\hline 建物用途 & 病院 \\
\hline 構造・規模 & $\mathrm{RC}$ 造 地上 7 階 \\
\hline 建築面積 & $9131.62 \mathrm{~m}^{2}$ \\
\hline 延床面積 & $33036.04 \mathrm{~m}^{2}$ \\
\hline 適用期間 & $2009 / 02 / 08-2009 / 07 / 25$ \\
\hline 対象部位 & 柱, 壁, 梁, 床, 階段 \\
\hline 打設工区 & 52 工区 \\
\hline 検査箇所 & 4467 \\
\hline 導入前準備 & 7 人日 \\
\hline 使用機器 & ファイルサーバ, パソコン 7 台 \\
\hline 検査体制 & (検査 + 写真) カ最大 4 班 \\
\hline 写真撮影枚数 & 49765 枚 \\
\hline
\end{tabular}

動的に振り分けられる。

（5）検査のまとめ

検查箇所と確認項目の一覧表示画面によって検查掞よ び写真撮影の進渉状況を確認する。すべての検査完了後 に，工区別管理表・部位別管理表・工事写真帳等の帳票 を出力する。また，検査で不具合があった場合は，不具 合箇所がキープランで確認できる是正記録表と，是正前 後の写真を対比した是正写真帳を出力する。

（6）変更への対応

運用中に計画変更があった場合は，対応する図面を差 し替える。また、コンクリートの打設範囲が変更になっ た場合は，工区の変更を行う。これらの変更は（2）の 検査の準備によって PDA とデジタルカメラに反映する。

\section{3 システムの効果}

当社では, 2009 年から本システムを建築工事の配筋 検査に扔ける標準ツールと位置付けている。本システム の適用事例として総合病院新築工事を説明する。この工 事では, 監理者から全数検查記録書類の提出が求められ た。従来方法で行った地下躯体工事の実績では，写真撮 影業務は 1 枚あたり 4.2 分, 写真整理業務は 1 日あたり 3 時間を要した。地上躯体工事ではこれら業務の増大が 予想されたため, 監理者と協議の結果，本システムの採 用を決定した。この時，工事写真に撮影箇所の配筋図を 記入した黒板を同時に撮影する必要がないことを確認し た。これは，工事写真を全数撮影するとともに，本シス テムで撮影箇所の配筋図を含んだ工事写真帳を作成でき るためである。

工事とシステム適用の概要を表-2に示す。適用期間 は地上躯体工事を行った約 6 カ月であった。検査対象部 位は, 柱・壁・梁・床・階段とし, 検査箇所数は 4467 箇所であった。検查体制は検查担当と写真担当を 1 組と して, 最大 4 班で検查を行った。検查結果と工事写真は 工事事務所内のサーバに保管し，工事管理者が利用する パソコン 7 台で検査結果を共有した。鉄筋工事の管理責 任者は写真-3に示すように進渉管理画面で検査の状況 を確認し、帳票と写真帳を出力した。 


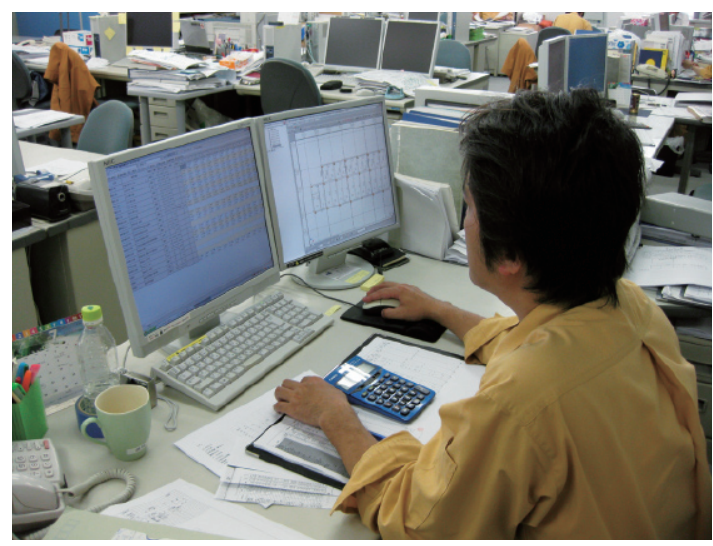

写真-3 配筋検査業務の進渉管理

表-3 工事写真管理に関する工数比較

\begin{tabular}{c|c|c}
\hline & 従来方法 & システム利用 \\
\hline $\begin{array}{c}\text { 工事写真撮影 } \\
\text { (分/枚) }\end{array}$ & 4.2 & 3.2 \\
\hline $\begin{array}{c}\text { 工事写真整理 } \\
\left(\begin{array}{c}\text { (分/日) } \\
\text { (1) }\end{array}\right.\end{array}$ & 180 & 10 \\
\hline
\end{tabular}

撮影した工事写真は 49765 枚で, 1 箇所平均約 11 枚 となった。表-3 は写真管理に関する作業工数を, 従来 方法と比較したものである。写真 1 枚あたりの撮影所要 時間は平均 3.2 分であった。これはシステム導入によっ て撮影䇢所の配筋図を黒板に記入する時間が不要になっ たためである。従来方法と比較して $24 \%$ の時間短縮で あり，地上躯体工事も従来方法で行った場合を想定する と, システム適用によって全配筋検査の撮影所要時間を 109 人日削減できたことになる。

工事写真の整理業務は，写真の仕分けやコメントの記 入がほぼ不要になったため，10 分/日程度の手間で済ん だ。これは従来方法と比較して $94 \%$ の時間短縮である。 地上躯体工事も従来方法で行った場合を想定すると， シ ステム適用によって全配筋検査の写真整理業務を 62 人 日削減できたことになる。

以上の上うに，工事写真の撮影と写真整理に特に大き な効果があったが，ヒアリング調査によって次のような 効果も確認できた。

1）施工現場での検査ではPDA のみで構造図等の多 くの図面を所持する必要がなくなった。

2）当該箇所の構造図だけでは気付きにくい柱主筋本 数などの上下階の変化が警告表示されるので, 見落 としを防げた。

3）検查項目がリスト化されているため，同一基準で 検査ができた。

4）複数班で同時に行った検查結果を, 簡単に統合で きたので，実質の検査時間を短縮できた。

5）検査項目ごとに確認日・確認者・写真枚数が記録 され，検査業務の進渉状況を一覧表示できるため, 検查や写真の過不足がなかった。

\section{4. タブレット端末への対応}

\section{1 機能追加のねらい}

携帯端末としてPDA を採用した理由は，小型パソコ ンに比べて軽量で可搬性が高く，バッテリーの持ちがよ く，比較的安価であることだった。一方，2010 年に Apple 社が iPad を発売してから，タブレット端末とい う新しい形式の携帯端末が施工現場でも利用可能になっ た。PDAに対するタブレット端末の利点は，次のよう になる。

1）画面サイズが約 4～9 倍と大きく，図面を表示し た場合の視認性が高い。

2）携带電話網を通じてインターネットに接続したり, 工事事務所の無線 LAN に接続できる機種がある。

3） 工事写真用に十分な解像度を持ったカメラを内蔵 した機種がある。

そこで，携带端末としてタブレット端末を利用できる ように，システムの機能追加を行った。タブレット端末 としては, カメラを内蔵した Apple 社の $\mathrm{iPad} 2$ を採用 した。システム開発を効率よく行うため，以下のねらい でシステムを改造した。

1）端末をPDA からタブレット端末に切換えるが, パソコンについては従来のシステムをそのまま扱え るようにする。

2）タブレット端末の内蔵カメラを利用し，写真管理 機能を強化する。

図-6に, 機能追加後のシステム構成を示す。従来シ ステムとの最大の相違点は, 携帯端末とパソコンとの デー夕同期にある。従来システムではパソコンから PDA 内のファイルを直接更新できたため, 表-1に示し たようにパソコンにデー夕同期機能を持たせた。一方, 今回採用したタブレット端末では，内部ファイルをパソ コンから操作できず，メモリーカード等を介したデー夕 交換もできない。そこで，工事事務所のファイルサーバ 内で常時稼働する同期サーバを開発し，タブレット端末 側からデータをダウンロード・アップロードできるよう にした。

\section{2 同期サーバの機能}

同期サーバは，ユーザーがログインしなくても常に起 動状態にあるプログラム（サービス／デーモン）として 実装した。通常は工事事務所内で共有するファイルサー バに設置する。同期サーバとタブレット端末との通信に

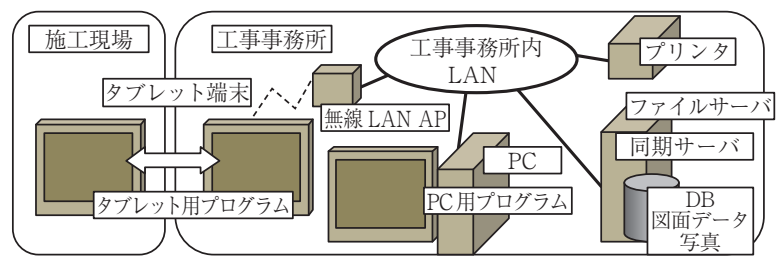

図-6 機能追加後のシステム構成 
は, HTTP (Hyper Text Transfer Protocol) を用いた。 これは, ファイヤーウォール等のセキュリティーの下で 比較的安定して通信できること，インターネットを介し た同期にも容易に対応できるためである。

同期サーバの機能は次の 7 点である。

1）アップロード：タブレット端末による検査結果 データおよび撮影した写真ファイルを, タブレット 端末から取り込む。

2）ダウンロード：図面・確認項目・検査箇所等の データおよび，他の異なるタブレット端末による検 査結果データと写真ファイルを, タブレット端末に 書き出す。

3）時計合わせ：情報の新旧を判別するために, サー バと端末と時計を一致させる。ただしタブレット端 末ではプログラムからの内部時計を操作できないた

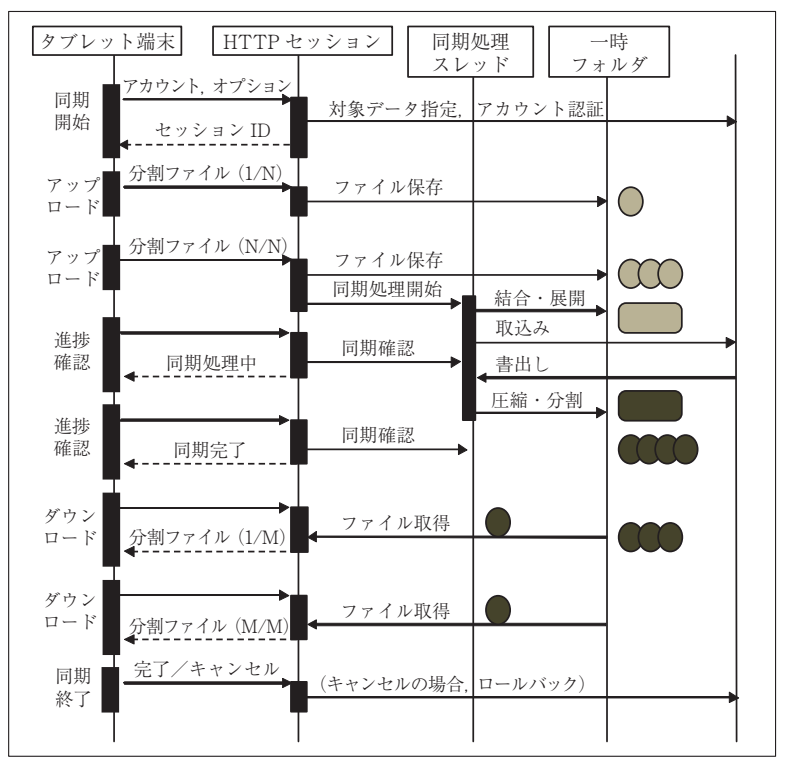

図-7 同期処理のシーケンス
め，サーバとの時間差を記憶し，デー夕更新や写真 撮影の際にこの時間差を反映して記録する。

4）データベース変換：データベースとして，パソコ ンでは Microsoft Access 用の mdbファイルを, 夕 ブレット端末ではSQLite 形式を使用している。同 期サーバで相互変換を行う。

5）図面データ変換：図面データは，あらかじめ複数 の単位イメージに分割することで表示の際のメモ リー使用量を最適にする独自フォーマット1)を採用 している。その単位イメージは, パソコンでは $\mathrm{JPEG} \cdot \mathrm{PNG} \cdot \mathrm{BMP}$ が利用できるが，タブレット端 末用にPNGに変換する。

6）サーバ制御機能：工事事務所内 LAN に接続した パソコンから, Web ブラウザでサーバを制御できる。

7）タブレット端末の接続制御：タブレット端末から 同期サーバの IP アドレスを設定して接続を申請し， サーバ制御機能で接続を許可する。

図-7に，同期処理のシーケンスを示す。本システム では, 図面・写真・検査結果など, 一度に大量の通信が 発生する可能性がある。HTTPは, クライアントの要 求にサーバが応答する一往復の通信である。一往復の通 信では, サーバ内で同期処理が完了するまで端末に応答 が返らない。そのため，ユーザーは同期処理の進渉が把 握できず，大量の通信が発生すると時間切れ（夕イムア ウト）になる場合がある。そこで，次の方法で同期処理 を行った。

1）同じ端末からのアクセスを, 一連の処理として認 識できるようにセッション管理を行う。

2）大規模なファイルは, 複数ファイルに分割して送 受信する。

3）端末との応答と同期処理を別処理として同時に行 う(マルチスレッド)。

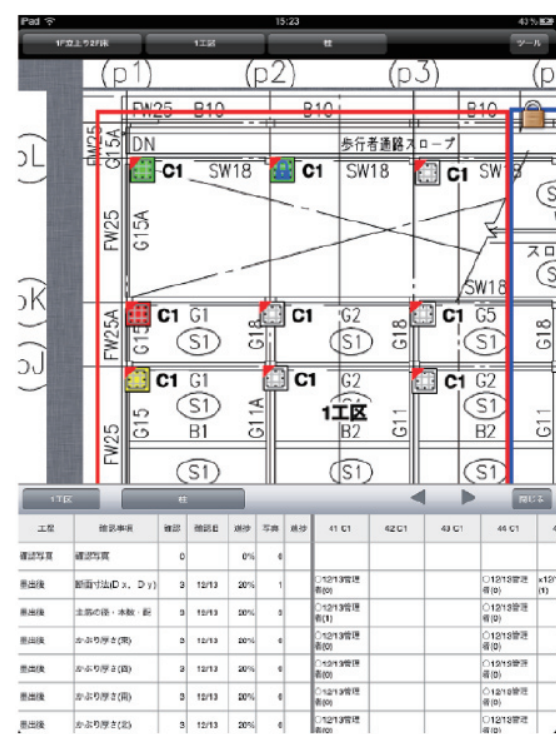

(a) 平面図表示画面

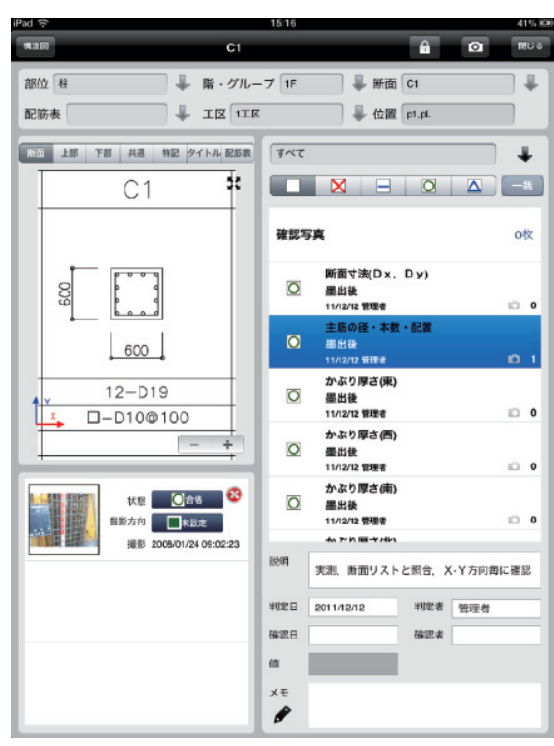

（b）断面表示および確認画面

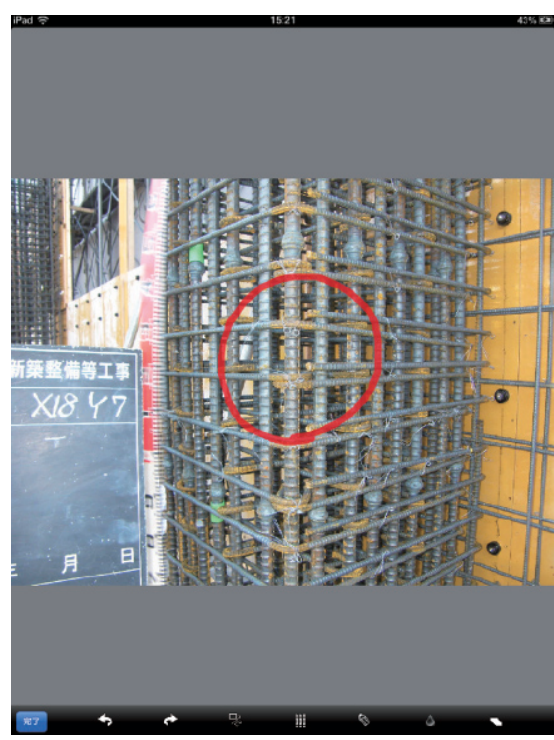

(c) アノテーション入力画面

図-8タブレット端末の検査内容確認画面 
これによってクライアントからの呼出しに 2 秒以内で 応答できるので，時間切れの心配がなく，ユーザーに同 期処理の進渉状況を提示できる。

\section{3 タブレット端末の機能}

タブレット端末用のプログラムは新たに開発した。 図-8にプログラムの画面を示す。PDAの画面（図-5） と比較して分かるように，平面図表示画面が広くなり図 面の視認性が向上した。パソコンの画面（図-3）と同様 に画面の下に検査箇所と検査項目のマトリックスを表示 し，検査業務の進渉状況を確認できるようにした。断面 表示と確認画面も 1 画面に統合し，操作性が向上した。

採用したタブレット端末はカメラを内蔵している。検 査箇所や検査項目を選択した状態で写真を撮影すれば, 写真と情報の紐づけが容易に行える。また，撮影した写 真の内容を，高解像度で確認できる。さらに，写真上に 注目箇所を手書きでマークしたり，コメントを記入でき るアノテーション機能を追加した。アノテーションの データは写真ファイルとは別に記録するので，写真ファ イルには一切変更を加えない。同期処理を行うと, 写真 ファイルとともにアノテーションデータもファイルサー
バに送る。写真帳を作成する際は，アノテーションデー タをメタファイル（WMF, EMF）に変換し, 写真に重 ね合わせて表示・印刷する。

\section{5.おわりに}

全箇所検査記録に対応した配筋検査支援システムを開 発し，実際の工事に適用した。その結果，鉄筋工事の品 質管理のトレーサビリティーを実現するとともに，検査 の手間を大幅に削減できることが分かった。また，同期 サーバを開発し，最小限の変更でタブレット端末にも対 応することができた。これからも，積極的な社内展開に よって鉄筋工事のさらなる品質向上を支援する所存で ある。

\section{参考文献}

1）金子ほか：携帯端末に対応した図面ベース情報共有ツールの開発 と適用，日本建築学会，建築生产シンポジウム，2006. 7

2）金子ほか: 全箇所・全数検查記録に対応した配筋検查支援システ ムの開発と適用、日本建築学会大会、建築生産シンポジウム, 2010. 6 